\title{
Paradox of Late Transition-Metal Catalysts in Ethylene Polymerization
}

\author{
Badral Gansukh, ${ }^{a, b}$ Randi Zhang, ${ }^{a, b}$ Jingjing Guo, ${ }^{c}$ Wenjuan Zhang ${ }^{*, a, c}$ and Wen-Hua Sun ${ }^{*, a, b,}$ \\ ${ }^{a}$ Key Laboratory of Engineering Plastics and Beijing National Laboratory for Molecular Sciences, \\ Institute of Chemistry, Chinese Academy of Sciences, Beijing 100190, China \\ ${ }^{b}$ CAS Research/Education Center for Excellence in Molecular Sciences, University of Chinese Academy \\ of Sciences, Beijing 100049, China \\ ${ }^{c}$ Beijing Key Laboratory of Clothing Materials R\&D and Assessment, Beijing Engineering Research Center \\ of Textile Nanofiber, School of Materials Science and Engineering, Beijing Institute of Fashion Technology, \\ Beijing 100029, China \\ ${ }^{d}$ State Key Laboratory for Oxo Synthesis and Selective Oxidation, Lanzhou Institute of Chemical Physics, \\ Chinese Academy of Sciences, Lanzhou, Gansu 730000, China
}

Email: zhangwj@bift.edu.cn (W. Z.), whsun@iccas.ac.cn (W. H. S.)

\begin{abstract}
Polyolefin materials are the most synthesized polymer used nowadays and symbolize the development level of the national petrochemical industry, in which polyethylenes are major along with alternative product $\alpha$-olefins for co-monomer and substrates for fine chemicals. Likely operating catalysts such as Ziegler-Natta and metallocene meet all demanding of various polyethylene materials, what is any business in developing late-transition metal catalysts for ethylene reactivity? In the past two decades, we realized the advantages of late-transition metal catalysts, such as easy variousness and easy preparation, good stability and high catalytic activity. Besides these, the characteristic different polyethylenes have been achieved as either highly linear polyethylene or highly branched polyethylenes. Therefore, there are some spaces in developing new catalytic system on the base of late-transition metal catalysts to compromise the demanding for new polyethylenes from sole ethylene polymerization.
\end{abstract}

Keywords homogeneous catalysis, $\mathrm{N}$ ligands, ligand effects, polymerization, polymers

\section{Introduction}

In the petrochemical industry, polyethylene along with $\alpha$-olefins are accounting for the largest sector of the markets. Polyethylene has excellent mechanical properties, process ability and chemical resistance, which is the most important polyolefin plastic and widely used in film, pipe and packaging materials. $\alpha$-Olefins are not only comonomers, but also the basic raw material for fine chemicals, using in synthetic detergents, plasticizers and lubricants. Nearly two decades ago, the revolutionary discovery of $\alpha$-diimine $\mathrm{Ni}(\mathrm{II})(\mathbf{1}$, Figure 1) and $\mathrm{Pd}(\mathrm{II})$ catalysts (2, Figure 1) for olefin polymerization/ oligomerization by Brookhart and co-workers ${ }^{[1]}$ has evoked much interest in the development of late-transition-metal polymerization catalysts. Subsequently, Brookhart ${ }^{[2]}$ and Gibson $^{[3]}$ independently reported bis(imino)pyridine-supported iron and cobalt precatalysts that are highly effective for ethylene polymerization or oligomerization, which have explored a new era in catalytic olefin polymerization that continues apace to this day. There were numerous review articles highlighting the progress in late transition metal pre-catalyst development and its structure influence on the resulting polyolefin products. ${ }^{[4-14]}$ Despite unique properties, the late transition metal catalysts
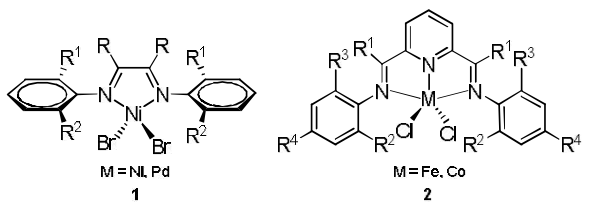

Figure 1 Representative late transition metal catalysts. suffer from poor thermostability that has limited their potential applications in industry (polymerization usually at $70-110^{\circ} \mathrm{C}$ ), which gives the impression of the researcher that it is difficult to be employed in the industrialized process system. Thus, the research of the late transition metal catalyst shows a downward trend in recent years. In addition to ethylene oligomerization, ${ }^{[15,16]}$ many results showed highly linear polyethylenes could be produced from iron/cobalt catalysts, ${ }^{[17-19]}$ while highly branched polyolefins could be prepared from nickel catalysts. ${ }^{[20,21]}$ Therefore, the polymer obtained by late transition metal catalysts not only has a special microstructure and properties, but also possesses the characteristics of high-performance polymeric materials. Our group have focused on the late transition metal complexes for ethylene polymerization. We found that the thermal stability of the catalyst is not an insurmountable technical barrier, and we have developed several series of high thermal stability late transition metal catalysts. ${ }^{[22-24]}$ Herein, we collect some of the recent results in this field with the main emphasis on the types of obtained polyethylenes by different mononuclear transition metal catalysts. We hope this review will illustrate the value of the research and furthermore encourage other researchers to be involved in the challenges ahead.

\section{Nickel Pre-catalysts}

In the past years, our group has been interested in further exploring the scope of versatility and thermal stability of well-defined nickel(II) complexes as pre-catalysts for ethylene polymerization (and oligomerization) and the results were collected in review. ${ }^{[12]}$ Besides being a source of academic 
interest, these new catalytic systems and their resulting polyethylene have displayed genuine potential for industrial applications. Notably, the formation of hyperbranched polyethylenes by nickel catalysts displaying properties characteristic of thermoplastic elastomers shows great promise for these materials to be employed as alternatives to elastomeric ethylene copolymers. ${ }^{[25-27]}$ With regard to the preparation and application of nickel catalysts, a large number of studies have started from the modification of $\alpha$-diimine ligand to form an extension of the bidentate $N^{\wedge} N$ system to $P^{\wedge} N,{ }^{[28-31]} P^{\wedge} P,{ }^{[32-33]}$ $\mathrm{N}^{\wedge} \mathrm{P}^{\wedge} \mathrm{N}^{[34]}$ and SHOP-types ${ }^{[35]}$ and other tridentate coordination systems. They will be introduced separately in the following.

\section{Nickel pre-catalysts bearing $\mathbf{N}^{\wedge} \mathbf{N}$-chelating ligands}

Since the seminal discovery that a-diimine-nickel complexes can efficiently catalyze the ethylene polymerization, ${ }^{[1]}$ the synthesis of structurally related $\mathrm{N}^{\wedge} \mathrm{N}$-nickel-based complexes has emerged as a hot topic in not only catalytic olefin polymerization but also coordination chemistry, and the research of related derivatization and new models are endless. In general, varying the backbones of the $\mathrm{N}^{\wedge} \mathrm{N}$-chelating ligands has a significant effect on the catalyst activity, as well as the polymer molecular weight and microstructure electronic and steric effects imparted by the substituted $\mathrm{N}$-aryl group. The mechanism of polymerization catalyzed by nickel complexes bearing $\mathrm{N}^{\wedge} \mathrm{N}$-chelating ligands is generally considered to be based on an active species comprising a cationic nickel-alkyl/ hydride; chain-walking ( $\beta-\mathrm{H}$ elimination/reinsertion) during the chain propagation step are the principal reasons for the formation of branched polyethylene. ${ }^{[12]}$ Deep mechanisms involved the combined effect of electronic and steric effects imparted by the substituted $\mathrm{N}$-aryl group are also significant and need to be further explored.

\section{Nickel precatalysts bearing $\alpha$-diimines}

Since the a-diimine ligand is prepared based on the reaction of hydrazine and butanedione and its derivatives with anilines ${ }^{[1]}$ researchers have carried out much work around the designing and synthesizing of such diketone skeletons. Beyond the represent work by Brookhart's group, ${ }^{[36]}$ Wu's group has also important contributions by improving the thermal stability of the a-diimine nickel precatalysts though incorporating the bulky backbones to the ligands. ${ }^{[37]}$ Besides, there are also lots of researches by international groups such as Coates, ${ }^{[38]}$ Alt, ${ }^{[39]}$ Rieger, ${ }^{[40]} \mathrm{Kim}^{[41]}$ and others. Guan have investigated the ethylene polymerization behavior of the cyclophane-containing a-diimine nickel precatalysts that showed very good thermal stability and activity for ethylene polymerization, which greatly attracted research enthusiasm and the desire for industrial development for scientists. ${ }^{[42]}$

Based on steric considerations, our group has also made some progress with improving the thermal stability of a-diimine-nickel precatalysts. ${ }^{[12]}$ By introducing a bulky group of benzhydryl $\left[\mathrm{CH}(\mathrm{Ph})_{2}\right]$ or difluorobenzhydryl $\left[\mathrm{CH}(p-\mathrm{FPh})_{2}\right]$ as the substituents on the $\mathrm{N}$-aryl groups, we have developed series modification of $\alpha$-diimine ligands and their corresponding nickel complexes. Complexes $3^{[26,27,43-46]}$ and $4^{[22-24]}$ containing one $\mathrm{N}$-aryl group appended with various benzhydryl substitution patterns, show outstanding catalytic activity for ethylene polymerization and providing the highly branched polyethylene. Notably, with the activation of either EASC or $\mathrm{Et}_{2} \mathrm{AICl}$, by incorporation of a para-nitro substituent, the resultant nickel precatalyst $3^{[46]}$ could produce the polyethylenes with ultra-high molecular weights (in the range of $10^{6} \mathrm{~g} \cdot \mathrm{mol}^{-1}$ ) with narrow molecular weight distributions. When the para- $\mathrm{R}$ group is $\mathrm{CH}(\mathrm{Ph})_{2}{ }^{[24]}$ or $t$-butyl, ${ }^{[27]}$ the more steric hindrance one, hyper-branched thermoplastic elastomers will be easy to obtain Very recently, our group have investigated the difference between homogeneous and immobilized 1-(2,6-dibenzhydryl-4nitrophenylimino)-2-mesityliminoacenaphthylnickel bromide as a precatalyst in ethylene polymerization and found that the activity was also improved. ${ }^{[47]}$ We have also developed nickel precatalyst $\mathbf{5}^{[48,49]}$ and $\mathbf{6}^{[50,51]}$ incorporating difluorobenzhydryl groups at the 2-position, 2,6-position or 2,4-position of either one or both $\mathrm{N}$-aryl groups. All these systems showed good thermal stability by maintaining high activity. We have also investigated the effect of benzhydryl and difluorobenzhydrylsubstitution on $\mathrm{N}$-naphthyl-containing unsymmetrical complexes 7, which can also improve the activity of ethylene polymerization and control the resulting polyethylene microstructures at the same time.$^{[52,53]}$ In addition, our group has targeted a new family of unsymmetrical nickel complexes 8 incorporating 4-R-2-methyl-6-cycloalkyl phenyl, ${ }^{[25]}$ which contains a cycloalkyl ortho-substituent that can be systematically modified in terms of ring size (viz., cyclopentyl vs. cyclohexyl vs. cyclooctyl). Comparing with previously work by $3{ }^{[43]}$ precatalyst 8 displayed some advantages in terms of higher catalytic activities and lower $T_{\mathrm{m}}$ thermoplastic elastomers (Figure 2). ${ }^{[25]}$
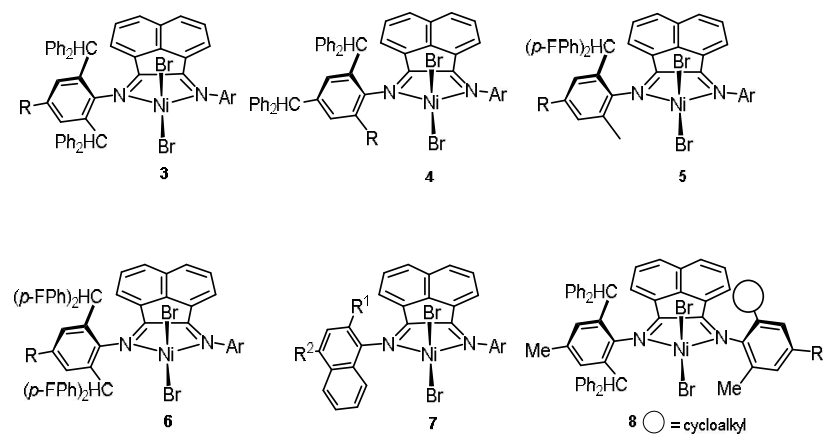

Figure 2 The nickel complexes bearing a-di(imino) acenaphthylene derivatives in our group.

\section{Nickel precatalysts bearing pyridinylimines and its derivatives}

Pyridylimine (and quinolinylimine) nickel complexes are another very attractive subject in recent years. Most of these complexes showed poor thermal stability for ethylene polymerization, and the catalytic product is oligomer or polyethylene waxes with low molecular weights, which are different with results by a-diimine-type nickel catalysts. Our group has developed a series of nickel complexes bearing quinolinylimines 9 that showed moderate to good activities for ethylene oligomerization that depends on the substituent $R$, which are of particular interest to researchers in this field. ${ }^{[54]}$ For example, with the activation of $\mathrm{Et}_{2} \mathrm{AICl}$, nickel precatalyst $9(\mathrm{R}=$ $\mathrm{Me})$ exhibited high activity for ethylene oligomerization $\left(12.4-18.3 \times 10^{5} \mathrm{~g} \mathrm{~mol}^{-1}(\mathrm{Ni}) \mathrm{h}^{-1}\right)$ with good thermal stability at $60{ }^{\circ} \mathrm{C}$. Since the backbone greatly affected their catalytic properties, our laboratory has investigated the effect of fused cycloalkyl groups of $N^{\wedge} N$-pyridinylimine-nickel catalysts $10^{[21,55-58]}$ and $11^{[59-63]}$ on the catalytic performance, which was prepared by hydrogenation of quinolinone that can efficiently catalyze the ethylene polymerization. When the skeleton contains a substituent group on the 2-positon of pyridine $(\mathrm{R}=$ $\mathrm{Me}, \mathrm{Cl}, \mathrm{Ph}),{ }^{[55-58]}$ the resultant nickel complex 10 can only catalyze the ethylene oligomerization. Without substituent on the pyridine, the obtained catalysts $\mathbf{1 1}$ with the different fused cycloalkyl showed better activity and produced the polyethylene waxes that can be used as additives to lubricants and pour-point depressants. ${ }^{[59-63]}$ However, there is always the imine-amine tautomerization in the ligand synthesis. In order to inhibit this tautomerization, by incorporating the two methyl 
group on the cycloalkyl ring, the nickel complexes 12 were prepared and evaluated for ethylene polymerization. ${ }^{[64,65]} \mathrm{A}$ detailed microstructural analysis of the resultant polyethylenes obtained by $12(n=1)^{[65]}$ revealed the presence of vinyl and higher levels of vinylene groups. These unsaturated materials could serve as macromonomer for preparing the copolymers with long chain branch or could be used for further functionalization. Furthermore, by introducing benzhydryl-substituted $N$-naphthyl groups into the pyridinylimine framework, the final nickel(II) complexes $\mathbf{1 3}$ have been developed in our group and they showed good activity for ethylene polymerization with producing the branched polyethylene of low molecular weight and narrow polydispersity (Figure 3). ${ }^{[6,67]}$

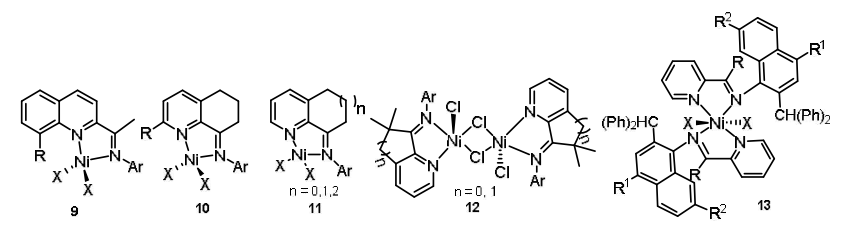

Figure 3 The $N^{\wedge} N$-chelating nickel complexes bearing pyridinylimine 9-13.

Nickel precatalyst bearing bidentate $N^{\wedge} O, N^{\wedge} P, P^{\wedge} O$ ligands

It should be mentioned that the nickel complexes chelating by $N^{\wedge} O, N^{\wedge} P$ and $P^{\wedge} O$-type ligands are also very important in the polyolefin field, in which the most research focused on the effects of the fine structure of the nickel complex on the catalytic activity and the selectivity for $\alpha$-olefins. In particular, the Nobel Prize winner Prof. Grubbs has reported the copolymerization of ethylene with polar monomers by this kind of nickel complexes, ${ }^{[68]}$ and the catalysts employed in Shell Higher Olefin Process (SHOP) resurrected nickel chemistry in the petrochemical industry was based on $\mathrm{P}^{\wedge} \mathrm{O}$ ligand, thereafter, ethylene oligomers could also be produced by a catalyst containing $\mathrm{N}^{\wedge} \mathrm{P}$-coordinated nickel catalysts. ${ }^{[69]}$ Braunstein, a well-known French chemist, has been conducting research on nickel complexes containing phosphorus ligands for many years, ${ }^{[28-30]}$ and our group has also reported some nickel complexes based on phosphine ligand. ${ }^{[70-74]}$

\section{Nickel pre-catalysts bearing $\boldsymbol{N}^{\wedge} \boldsymbol{N}^{\wedge} \boldsymbol{N}$ tridentate ligands}

The application of $N^{\wedge} N$ bidentate nickel complexes in olefin oligo-/polymerization has attracted much attention, but there were still a lot of research about $N^{\wedge} N^{\wedge} N$ tridentated nickel complexes for ethylene polymerization. ${ }^{[75,76]}$ Much promising work in this area has been conducted in recent years and they showed moderate to good activity for ethylene oligomerization or polymerization. The most typical are bis(arylimino)pyridyl nickel complexes $14^{[77]}$ and its derivatives $15^{[78-81]}$ as well as nickel complexes formed by oxygen-nitrogen ligands (Figure $4){ }^{[82]}$ A large number of related studies have shown that despite the internal factors of the complex, the catalytic conditions could also affect the activity and product properties in the catalytic process
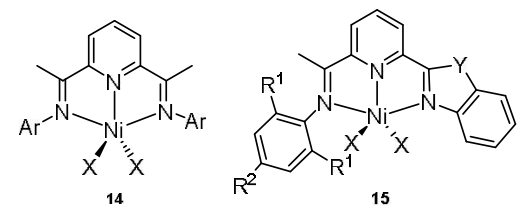

Figure 4 The tridentate nickel complexes $\mathbf{1 4}$ and $\mathbf{1 5}$.

In addition to the mononuclear nickel pre-catalysts described above, the potential for synergic effects promoted by the presence of two catalytic active species held in close proximity has continued to attract attention. ${ }^{\left[{ }^{83,84]}\right.}$ Most of the reported complexes, on activation by MAO or MMAO, formed low molecular weight waxes or oligomeric materials.

\section{Iron/cobalt precatalysts}

Over recent years, there have been some notable advances in the development of iron and cobalt complexes supported by pincer ligands, which were verified to promote a wide variety of important transformations including (i) the hydrogenation of olefins, carbonyl compounds, carboxylic acid derivatives and $\mathrm{CO}_{2},{ }^{[85-94]}$ (ii) the dehydrogenation of alcohols, amines and alkanes, ${ }^{[95-100]}$ (iii) the transfer hydrogenation reactions, ${ }^{[101]}$ and (iv) the dehydrogenative cross-coupling. ${ }^{[102-104]}$ More importantly, iron and cobalt complexes have proved to be good potential catalysts for olefin polymerization, ${ }^{[4-14,105-108]}$ but also for oligomerization to produce $\alpha$-olefin. ${ }^{[7,8,108]}$ Indeed, the recent successful five-hundred ton process pilot using iron catalyst for producing $\alpha$-olefins in our group highlights the vast industrial significance of such catalysts. Herein, we collected the key developments in iron and cobalt catalyst technology that have been explored in the last decade with a focus on development of the structural features of the pre-catalyst and in particular the auxiliary ligand that dedicated catalyst performance.

\section{$\mathrm{Fe} / \mathrm{Co}$ pre-catalysts bearing bis(arylimino)pyridines}

The first generation systems of iron and cobalt catalysts based on bis(arylimino)pyridine pincer ligands for ethylene oligo-/polymerization were disclosed by the Brookhart ${ }^{[2]}$ and Gibson ${ }^{[3]}$ groups in 1998. They found that the iron or cobalt complexes incorporating alkyl groups at the ortho- and para-positions of the $\mathrm{N}$-aryl groups when activated with methyl alumoxane (MAO) or modified methylaluminoxane (MMAO), exhibited high activity in ethylene polymerization (up to $206.0 \times$ $10^{6} \mathrm{~g}$ of PE mol ${ }^{-1}(\mathrm{Fe}) \mathrm{h}^{-1}$ and $17.0 \times 10^{6} \mathrm{~g}$ of PE $\left.\cdot \mathrm{mol}^{-1}(\mathrm{Co}) \cdot \mathrm{h}^{-1}\right)$ with producing the high density/highly linear polyethylene with high molecular weight $\left(\mathrm{M}_{\mathrm{w}} \sim 10^{5} \mathrm{~g} \cdot \mathrm{mol}^{-1}\right){ }^{[109]}$ Moreover, complexes containing $\mathrm{N}$-aryl groups substituted by less bulky substituents at the ortho-positions produced oligomers with activities up to $10^{6} \mathrm{~g}$ (oligomer) $\cdot \mathrm{mmol}^{-1}(\mathrm{Fe}) \cdot \mathrm{h}^{-1}$ at $90^{\circ} \mathrm{C} .^{[110,111]}$

In subsequent years, considerable efforts emerged in succession as for modifying the bis(arylimino)pyridines with the aim of enhancing the catalytic behavior and thermal stability of their complexes. Qian's group in 2002 introduced 2,6-dihalide substituted $\mathrm{N}$-aryl groups exhibited by far the highest activity amongst this series while the fluoride-substituted iron complexes give high selectivity (> 93\%) for linear a-olefins. ${ }^{[12,113]}$ After that, iron and cobalt complexes bearing symmetrical and/or unsymmetrical bis(arylimino)pyridines with the influence of the para-substituent on the $\mathrm{N}$-aryl rings for ethylene polymerization were investigated in several group. ${ }^{[113-120]}$ Xie also reported the effect of alkyl and halide substituents of unsymmetrical bis(arylimino)pyridine-iron complexes containing on ethylene oligomerization. The obtained products were mainly linear $\alpha$-olefins (up to 98\%) with the distribution between $\mathrm{C}_{4}$ and $\mathrm{C}_{24}$, and no polymer product was observed. ${ }^{[121]}$

In order to improve the thermal stability of late transition metal pre-catalysts, the introduction of more sterically bulky $\mathrm{N}$-aryl groups to the bis(arylimino)pyridine ligand frame has been the subject in numerous reports and indeed this modification has produced some encouraging results and the relative results were collected in several reviews. ${ }^{[6,8,13]}$ Wu's group has reported three iron complexes containing bulky $\mathrm{N}$-aryl groups maintained a high activity at $70^{\circ} \mathrm{C}$ and displayed relatively stable kinetics although leading to the formation of products of lower molecular weight at elevated temperature activated with MAO for ethylene polymerization. ${ }^{[122]}$ Over the last five years, our group has also been interested in improving 
the catalytic behavior and thermal stability of bis(arylimino)pyridine iron and cobalt complexes. In particular, we have found that by introduction of sterically benzhydryl groups into bis(imine)pyridines the resulting iron and cobalt catalysts showed better thermal stability than their parent analogues. ${ }^{[123-136]}$ Iron complex 16 displayed high activity up to $22.4 \times 10^{6} \mathrm{~g}$ of $\mathrm{PE} \cdot \mathrm{mol}^{-1}(\mathrm{Fe}) \cdot \mathrm{h}^{-1}$ at $80^{\circ} \mathrm{C}$, indicating good thermal stability. ${ }^{[123]}$ The obtained polyethylenes were all strictly linear with broad molecular weight distributions. The cobalt analogues 17 also displayed high activities than reported parent cobalt pre-catalysts, with values as high as $4.64 \times 10^{6} \mathrm{~g}$ $\mathrm{PE} \cdot \mathrm{mol}^{-1}(\mathrm{Co}) \cdot \mathrm{h}^{-1}$ for ethylene polymerization at atmospheric pressure. The polyethylenes obtained were of high molecular weight and narrow molecular weight distribution. ${ }^{[124]}$ When the para-R group is $\mathrm{Cl}$ (electron withdrawing), iron complex 18 showed higher activities up to $24.6 \times 10^{6} \mathrm{~g} \cdot \mathrm{PE} \cdot \mathrm{mol}^{-1}(\mathrm{Fe}) \cdot \mathrm{h}^{-1}$ at $60{ }^{\circ} \mathrm{C}$ for ethylene polymerization when activated by MMAO. The obtained PE possessed higher molecular weight polyethylene $\left(M_{\mathrm{w}}=42.0 \mathrm{~kg} \cdot \mathrm{mol}^{-1}\right)$ than complexes $16\left(\mathrm{M}_{\mathrm{w}}=\right.$ $\left.25.5 \mathrm{~kg} \cdot \mathrm{mol}^{-1}\right)$. The cobalt analogues 19 also showed good activity for ethylene polymerization. ${ }^{[125,126]}$ When the paraposition of ${ }^{t} \mathrm{Bu}$ and $\mathrm{NO}_{2}$ substituents on aryl group, the iron pre-catalysts 20 and 21 (Figure 5) with MMAO exhibited high activity as $35.1 \times 10^{6} \mathrm{~g} \cdot \mathrm{PE} \cdot \mathrm{mol}^{-1}(\mathrm{Fe}) \cdot \mathrm{h}^{-1}$ at $80^{\circ} \mathrm{C}(20)$ and $40.2 \times 10^{6} \mathrm{~g} \cdot \mathrm{PE} \cdot \mathrm{mol}^{-1}(\mathrm{Fe}) \cdot \mathrm{h}^{-1}$ at $50{ }^{\circ} \mathrm{C} \quad(21) \cdot{ }^{[127,128]}$ In comparison with the parent bis(imine)pyridine iron complexes containing ortho-alkyl and para- $\mathrm{NO}_{2}$, catalytic activity by $\mathbf{2 0}$ or 21 was greatly improved with almost seven-fold increasing. In case of $\mathrm{R}={ }^{\mathrm{t}} \mathrm{Bu}$, the polyethylene obtained by 21 possessed low molecular weight and strictly linear polyethylene. However, the incorporation of $\mathrm{NO}_{2}$ substituent into iron catalysts led to high molecular weight ethylene polymer with broad molecular weight distributions. By stark contrast, the symmetrical iron and cobalt complexes 22-26 bearing two bulky 2,6-dibenzhydryl phenyl groups on ortho-position showed very poor activity with only trace amounts of polymer due to too much steric bulk groups preventing the ethylene insertion. ${ }^{[123-128]}$

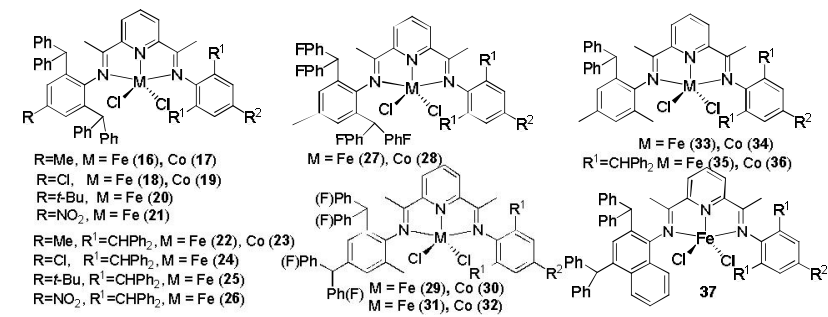

Figure 5 Benzhydryl-substituted bis(imino)pyridine $\mathrm{Fe} / \mathrm{Co}$ complexes 16-37.

When difluorobenzhydryl groups were incorporated into bis(imine)pyridines, the resultant bulky unsymmetrical iron and cobalt catalysts $\mathbf{2 7}$ and $\mathbf{2 8}$ showed better thermal stability and high catalytic activity. ${ }^{[129,130]}$ Among them the iron complexes, 27 basically exhibited higher activity (up to $3.5 \times 10^{7} \mathrm{~g} \cdot \mathrm{PE} \cdot \mathrm{mol}^{-1}$ $(\mathrm{Fe}) \cdot \mathrm{h}^{-1}$ in $15 \mathrm{~min}$ ) for ethylene polymerization than their cobalt complexes 28 (up to $7.6 \times 10^{6} \mathrm{~g} \cdot \mathrm{PE} \cdot \mathrm{mol}^{-1}(\mathrm{Co}) \cdot \mathrm{h}^{-1}$ ). Complexes 29 ( $\mathrm{Fe}$ ) and 30 ( $\mathrm{Co}$ ) based on 2,4-substitutent exhibited a relatively lower activity but still up to $2.0 \times 10^{7}$ $\mathrm{g} \cdot \mathrm{PE} \cdot \mathrm{mol}^{-1}(\mathrm{Fe}) \cdot \mathrm{h}^{-1}$ and $3.7 \times 10^{6} \mathrm{~g} \cdot \mathrm{PE} \cdot \mathrm{mol}^{-1}(\mathrm{Co}) \cdot \mathrm{h}^{-1}$ than their iron and cobalt analogs 27 and 28. ${ }^{[131,132]}$ The complexes 31 and 32 with 2,4-difluorobenzhydrylphenyl group also exhibited low activity for ethylene polymerization. ${ }^{[133]}$

Several kinds of bis(imino)pyridine iron and cobalt complexes 33-36 bearing only one ortho-dibenzhydryl group also showed high activity (up to $15.7 \times 10^{6} \mathrm{~g} \cdot \mathrm{PE} \cdot \mathrm{mol}^{-1}(\mathrm{Fe}) \cdot \mathrm{h}^{-1}$ ) in the presence of either MAO or MMAO for ethylene polymerization. ${ }^{[134]}$ While bis(imino)pyridine iron complexes 37 (Figure 5) containing the benzhydrylnaphthyl group also displayed good activities up to $15.8 \times 10^{6} \mathrm{~g} \cdot \mathrm{PE} \cdot \mathrm{mol}^{-1}(\mathrm{Fe}) \cdot \mathrm{h}^{-1}$ and better thermal stability (optimum temperature was $70^{\circ} \mathrm{C}$ ) with MMAO as co-catalyst. ${ }^{[135]}$

\section{Other phenanthroline or quinoline based $\mathrm{N}, \mathrm{N}, \mathrm{N}$-ligated Fe/Co complexes}

Beyond the modification of the parent bis(arylimino)pyridine frame to achieve higher catalytic activity, better thermal stability and more control of the polymer microstructure ${ }^{[6,8,13]}$ the iron or cobalt complexes bearing other new $N, N, N$ backbone have also been developed. In 2002, our group has investigated a series of late transition metal complexes $(38,39)$ ligated by 2,9-bis(arylimino)-1,10-phenanthroline ligands for oligomerization and/or polymerization. ${ }^{[136]}$ The results showed that the cobalt complexes exhibited good catalytic activities for ethylene oligomerization, while the iron analogues displayed low activities for ethylene polymerization. This observation was ascribed to the detrimental coordination of the additional imino group to the metal ( $\mathrm{Fe}$ or $\mathrm{Co}$ ) center during propagation thereby disturbing the ethylene coordination and thus decreasing the catalytic activity. ${ }^{[136]}$ The similar result was also reported by Gibson's group. ${ }^{[137]}$ In consideration of this undesirable coordination, 2-imino-1,10-phenanthroline derivatives and their iron and cobalt complexes $\mathbf{4 0}$ and $\mathbf{4 1}$ were developed by group for the first time in $2006 .^{[138,139]}$ Independently, Solan group was also aware of the beneficial properties of 2-imino-1,10-phenan throlines in late transition metal catalysis and reported their findings on cobalt complexes in the same year. ${ }^{[140]}$ These tridentate iron complexes exhibited the highest activity (up to $4.91 \times 10^{7} \mathrm{~g} \cdot \mathrm{mol}^{-1}(\mathrm{Fe}) \cdot \mathrm{h}^{-1}$ ) for ethylene oligomerization among its analogs, and with high selectivity for a-olefins (>94\%) with the oligomers displaying Schulz-Flory distributions. ${ }^{[138]}$ Of particular note, these iron complexes have been successfully used in a 500 ton per year pilot process for making a-olefins. By changing $\mathrm{R}$ from methyl to ethyl (40), the obtained iron complexes still showed good activity for ethylene oligomerization, but the distribution of oligomers changed with less content of butane..$^{[141]}$ In addition, it was found that the ortho-substituents on the $\mathrm{N}$-aryl group in iron complexes greatly influence the activity and the distribution of a-olefin product. When a phenyl group was introduced at the 9-position of the 1,10-phenanthroline ${ }^{[142]}$ the resulting iron/cobalt complexes 42-43 only catalyzed ethylene oligomerization with producing the short chain $\mathrm{C}_{4}$ as major (>90\%) and a little $\mathrm{C}_{6}$ fractions with no evidence for polymer formation. Replacement of the imine group with benzimidazoles $(\mathbf{4 4}, \mathbf{4 5})$ or 2-benzoxazole $(\mathbf{4 6}, \mathbf{4 7})$ or an oxazoline $(\mathbf{4 8}, 49)$ also greatly influenced catalytic activity and the resulting oligomers. ${ }^{[143,144]}$

Our group has also studied the catalytic behavior of iron and cobalt complexes containing alternative $N, N, N$ ligand for ethylene oligo-/polymerization. ${ }^{[145-151]}$ The iron/cobalt complexes $\mathbf{5 0 - 5 1}$ bearing a 2-quinoxalinyl-6-iminopyridine, in the presence of MAO, showed high activity (up to $10^{6} \mathrm{~g} \cdot \mathrm{mol}^{-1}$ $(\mathrm{Fe}) \cdot \mathrm{h}^{-1}$ ) for ethylene oligomerization with $\mathrm{C}_{4}$ as the major product $(\sim 95 \%)$ at atmospheric pressure. ${ }^{[145]}$ The iron and cobalt 52-54 containing 2-(2-benzimidazolyl)-6-(1-(arylimino)ethyl) pyridines showed high activity up to $4.11 \times 10^{6}$ $\mathrm{g} \cdot \mathrm{mol}^{-1}(\mathrm{Fe}) \cdot \mathrm{h}^{-1}$ towards ethylene oligomerization. Some formation of polyethylene waxes was also observed. ${ }^{[146-149]}$ 2-Benzoxazolyl-6-(1-(arylimino) ethyl)pyridyl cobalt complexes 55 displayed moderate activity as $7.5 \times 10^{5} \mathrm{~g} \cdot \mathrm{mol}^{-1}(\mathrm{Co}) \cdot \mathrm{h}^{-1}$ toward ethylene oligomerization with good selectivity of $\alpha$-olefin. ${ }^{[150,151]}$ The iron complexes 56 containing 2-( $\beta$-benzothiazolyl)-6-[1-(arylimino)ethyl]pyridine showed high activity up to $10^{7} \mathrm{~g} \cdot \mathrm{mol}^{-1} \cdot(\mathrm{Fe}) \cdot \mathrm{h}^{-1}$ for ethylene oligo-/polymerization, with 
high selectivity for vinyl-terminated oligomers or polyethylene waxes (Figure 6). ${ }^{[148]}$

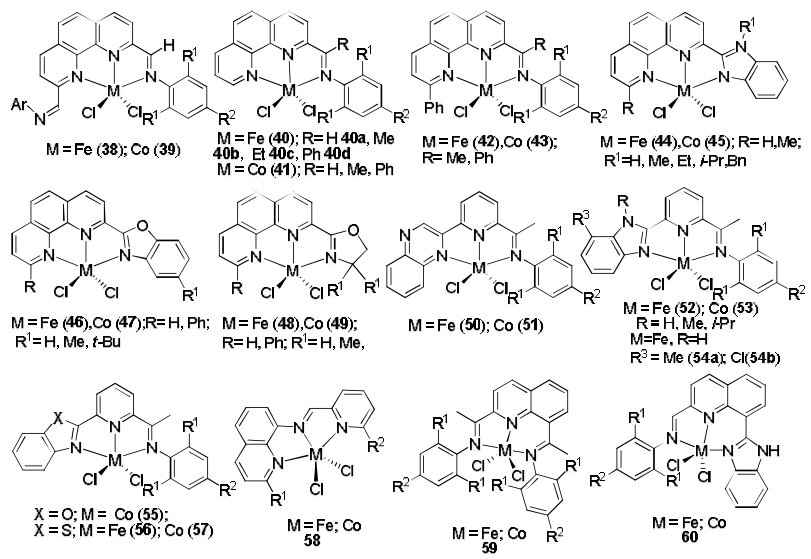

Figure 6 Other $N^{\wedge} N^{\wedge} N$ tridentate iron or cobalt complexes, $38-60$.

Gibson et al. investigated the use of iron complex bearing 6 -aryliminoethyl-2,20-bipyridine as the $N, N, N$-ligand for ethylene oligomerization. ${ }^{[137,152]}$ Subsequently, Yasuda group screened the catalytic behavior of iron complexes chelated by the tri-pyridine derivatives for olefin polymerization. ${ }^{[153]}$ The iron and cobalt pre-catalysts containing $\mathrm{N}$-aryl-functionalized 2,6-bis[3(5)-pyrazolyl]pyridines resulted highly linear polyethylene with high molecular weight. ${ }^{[154]}$ Tenza group has also studied the catalytic behavior of bis(imidazole)/ (carbene)pyridine-iron complexes for ethylene polymerization. ${ }^{[155]}$

Beyond the above examples, our group has developed several series of quinoline based $N, N, N$ tridentate iron and cobalt complexes 58-60. ${ }^{[156-158]}$ Iron complex 58 efficiently catalyzed the ethylene oligomerization with the product of butene and hexene (the activity is up to $\left.10^{6} \mathrm{~g} \cdot \mathrm{mol}^{-1}(\mathrm{Fe}) \cdot \mathrm{h}^{-1}\right) \cdot{ }^{[156]}$ The iron complex 59 bearing 2,8-bis(arylimine)quinolines showed no reactivity for ethylene, but it displayed quite good activity for ethylene polymerization at $80^{\circ} \mathrm{C}$ and kept the activity of $7.61 \times 10^{6} \mathrm{~g} \cdot \mathrm{PE} \cdot \mathrm{mol}^{-1}(\mathrm{Fe}) \cdot \mathrm{h}^{-1}$ even at $100{ }^{\circ} \mathrm{C} .^{[157]}$ The replacement of the arylimine group with benzimidazolyl led to the decrease of polymerization activity $\left(10^{5} \mathrm{~g} \cdot \mathrm{PE} \cdot \mathrm{mol}^{-1}(\mathrm{Fe}) \cdot \mathrm{h}^{-1}\right)$ by the resultant iron complexes $60^{[158]}$

\section{Cycloalkyl-fused bis(arylimino)pyridines and their $\mathrm{Fe} / \mathrm{Co}$ precatalysts}

During the last five years, our group has systemically investigated the effect of ring strain on the performance of nickel catalysts for ethylene polymerization. ${ }^{[55-63]}$ We have also successfully prepared tridentate iron or cobalt complexes 61-78 containing singly and doubly cycloalkyl-fused bis(arylimino) pyridines with the alkyl ring sizes from five to eight (Figure 7). ${ }^{[159-171]}$ In comparison with catalysts bearing the parent $N, N, N$-bis(aryl imino)pyridine framework, these second

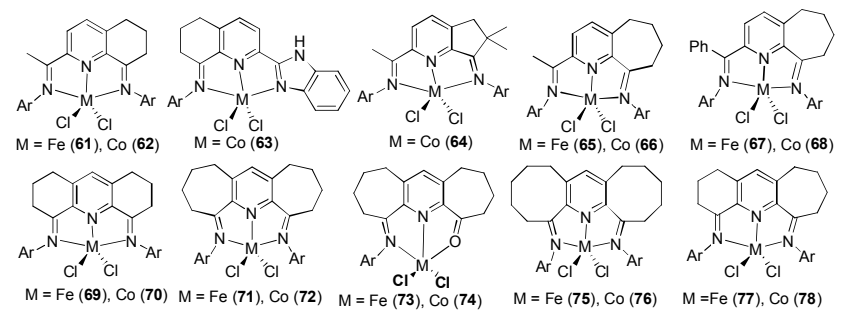

Figure 7 Cycloalkyl-fused bis(arylimino)pyridyl iron and cobalt complexes generation iron and cobalt complexes have displayed unique performance for ethylene polymerization with much better thermal stabilities and selective formation of polyethylenes.

The iron and cobalt pre-catalysts 61 and 62 bearing 2-(1-arylimino)methyl-8-arylimino-5,6,7-tetrahydroquinolines, exhibited high activities and good thermal stability for ethylene polymerization. Iron catalysts $\mathbf{6 1}$ displayed high activity (up to $1.5 \times 10^{7} \mathrm{~g} \cdot \mathrm{PE} \cdot \mathrm{mol}^{-1}(\mathrm{Fe}) \cdot \mathrm{h}^{-1}$ ) for ethylene polymerization at 50 ${ }^{\circ} \mathrm{C}$, generating highly linear polyethylene $\left(\mathrm{M}_{\mathrm{w}}=2.2 \times 10^{4}\right.$ $\left.\mathrm{g} \cdot \mathrm{mol}^{-1}\right) \cdot{ }^{[159]}$ Their cobalt analogs 62 also displayed high activities up to $1.1 \times 10^{7} \mathrm{~g} \cdot \mathrm{PE} \cdot \mathrm{mol}^{-1}(\mathrm{Co}) \cdot \mathrm{h}^{-1}$ with producing the lower molecular weight PE with narrow PDIs. ${ }^{[160]}$ While cobalt complexes 63 bearing 2-benzoimidazolyl-8-arylimino-5,6,7trihydroquinolines displayed moderate activity toward ethylene oligomerization (highest activity of $1.23 \times 10^{5} \mathrm{~g} \cdot \mathrm{mol}^{-1}(\mathrm{Co}) \cdot \mathrm{h}^{-1}$ ) with producing 1-butene and 1-hexene. ${ }^{[161]}$ Cobalt complexes 64 containing a smaller fused cyclopentyl ring, showed much lower activities on activation with MAO $\left(2.89 \times 10^{4} \mathrm{~g} \cdot \mathrm{PE} \cdot \mathrm{mol}^{-1}\right.$ (Co) $\cdot h^{-1}$ ) than that seen for $\mathbf{6 2}$ with producing higher molecular weight of polymer $\left(\sim 10^{5} \mathrm{~g} \cdot \mathrm{mol}^{-1}\right)$. Under the activation of MMAO, 64 showed moderate activity for ethylene oligomerization $\left(10^{5} \mathrm{~g} \cdot \mathrm{mol}^{-1}(\mathrm{Co}) \cdot \mathrm{h}^{-1}\right) \cdot{ }^{[162]}$ Pre-catalysts Iron(II) chlorides incorporating seven-membered rings 65 and 67 showed high activities up to $1.5 \times 10^{7} \mathrm{~g} \mathrm{PE} \cdot \mathrm{mol}^{-1}(\mathrm{Fe}) \cdot \mathrm{h}^{-1}$ for ethylene polymerization. ${ }^{[163,164]}$ Due to the bulkier group of phenyl, 67 showed better thermal stability and possessed longer life time than 65 . Cobalt complexes 66 and 68 also displayed good activity (up to $8.6 \times 10^{6} \mathrm{~g} \cdot \mathrm{PE} \cdot \mathrm{mol}^{-1} \cdot(\mathrm{Co}) \cdot \mathrm{h}^{-1}$ ) for ethylene polymerization, producing the polyethylene wax $\left(\mathrm{M}_{\mathrm{w}}: 3\right.$ $\mathrm{kg} \times \mathrm{mol}^{-1}$ ) that containing the vinyl-end group. ${ }^{[166,167]}$

The doubly cyclohexyl-fused bis(arylimino)pyridine iron and cobalt complexes 69 and $\mathbf{7 0}$ have been reported by Kim and they exhibited good activity $\left(3.6 \times 10^{6} \mathrm{~g} \cdot \mathrm{PE} \cdot \mathrm{mol}^{-1}(\mathrm{Fe}) \cdot \mathrm{h}^{-1} \cdot \mathrm{bar}^{-1}\right.$ and $\left.2.9 \times 106 \mathrm{~g} \cdot \mathrm{PE} \cdot \mathrm{mol}^{-1}(\mathrm{Co}) \cdot \mathrm{h}^{-1} \cdot \mathrm{bar}^{-1}\right)$ for ethylene oliogmerization and polymerization. ${ }^{[167]}$ While the doubly seven-ring fused bis(arylimino)pyridine iron complexes 71 exhibited quite high activity (up to $12.8 \times 10^{6} \mathrm{PE} \cdot \mathrm{mol}^{-1}(\mathrm{Fe}) \cdot \mathrm{h}^{-1}$ ) for ethylene polymerization with producing the linear polyethylene with viny group. ${ }^{[168]}$ In contrast, the activity by 72 is lower but still up to $3.6 \times 10^{6} \mathrm{PE} \cdot \mathrm{mol}^{-1}(\mathrm{Co}) \cdot \mathrm{h}^{-1}$ and the resulting PE possessed low molecular weight and narrow distribution. ${ }^{[169]}$ Very recently, by incorporating one bulky group of $\mathrm{CHPh}_{2}$, the precatalyst $\mathbf{7 1}$ exhibited quite high activity for ethylene polymerization $\left(3.81-3.93 \times 10^{7} \mathrm{~g}(\mathrm{PE}) \cdot \mathrm{mol}^{-1}(\mathrm{Fe}) \cdot \mathrm{h}^{-1}\right)$ at $80^{\circ} \mathrm{C}$, producing the polywax with very narrow distributions $(\mathrm{PDI}=1.1) .{ }^{[170]}$ After scale up, ethylene polymerization activity by 71 could reach $48.10 \times 10^{6} \mathrm{~g}(\mathrm{PE}) \cdot \mathrm{mol}^{-1}$, which is better than in the laboratory. When two bulkyl group of $\mathrm{CHPh}_{2}$ was incorporated on the ortho-postion of $\mathrm{N}$-aryl, the expected bis(imino)pyridines iron or cobalt complexes could not successfully be prepared and the NNO coordinated complexes 73 and 74 were prepared. ${ }^{[171]}$ The cobalt complexes $\mathbf{7 4}$ showed moderate activities for ethylene oligomerization $\left(10^{5} \mathrm{~g} \cdot \mathrm{mol}^{-1}(\mathrm{Co}) \cdot \mathrm{h}^{-1}\right)$ and producing $\alpha$-olefins $\left(\mathrm{C}_{4} \sim \mathrm{C}_{30}\right)$ with broad distribution. However, iron analogues 73 showed much lower activities (around $10^{4} \mathrm{~g} \cdot \mathrm{mol}^{-1}(\mathrm{Co}) \cdot \mathrm{h}^{-1}$ ) for ethylene polymerization.

We have also developed a series of $\alpha, \alpha^{\prime}$-bis(arylimino)2,3:5,6-bis(hexamethylene)pyridine iron complexes 75 that exhibited high activity as $3.38 \times 10^{7} \mathrm{~g} \cdot \mathrm{PE} \cdot \mathrm{mol}^{-1}(\mathrm{Fe}) \cdot \mathrm{h}^{-1}$ for ethylene polymerization, producing the highly linear and low molecular weight polymer. ${ }^{[172]}$ While cobalt complexes 76 with the same ligand exhibited high activity up to $6.60 \times 10^{6}$ $\mathrm{g} \cdot \mathrm{PE} \cdot \mathrm{mol}^{-1}(\mathrm{Co}) \cdot \mathrm{h}^{-1}$ for ethylene polymerization and producing highly linear polyethylenes. ${ }^{[13]}$ The different alkyl-ring fused pyridyl iron and cobalt complexes $\mathbf{7 7}$ and $\mathbf{7 8}$ also displayed high activity for ethylene polymerization with producing strictly linear polyethylene waxes with a narrow molecular weight 
distributions. The polymer obtained with $\mathrm{MAO}$ as cocatalyst possessed high content of vinyl group $\left(\mathrm{CH}=\mathrm{CH}_{2}\right) .{ }^{[174,175]}$

In general, the iron and cobalt catalysts can often form polymers with different kinds, e.g., linear $\alpha$-olefins accompanied by waxes or oligomers from ethylene oligomerization or multimodal or broad molecular weight distributions for ethylene polymerization. For the catalytic mechanism of these precatalysts, it is generally accepted that bis(arylimino)pyridineiron and -cobalt catalysts propagate by a Cossee-Arlman mechanism, ${ }^{[176]}$ in which sequential ethylene coordination and migratory insertion of the bound ethylene into a metal alkyl bond occur before some form of chain terminates occurs, thence the influence of the ligand structure is also significant which shows electronic and steric effects. However, the formation, the nature, and the reactivity of the intermediates involved still need to be investigated and elucidated.

\section{Conclusion}

The discovery of ethylene oligomerization and polymerization catalyzed by late transition metal complexes shows that the catalyst is simple to prepare, the catalytic activity is high, and the obtained products are different depending on the metal. Iron or cobalt-based catalysts could generate highly linear (polyethylene and $\alpha$-olefin) products, which are suitable for the industrial production of ethylene oligomerization to produce a-olefins, as well as polyethylene waxes and functional polyethylenes containing terminal double bonds. Nickel-based catalysts mostly obtain highly branched products suitable for the preparation of polyethylene elastomers and oil additives or pour point depressants. Obviously, these polyethylenes could not be produced by traditional Ziegler-Natta and metallocene catalysts. The late transition metal complexes are easily prepared with low cost and they are also easy to handle in the polymerization due to their non-sentitive to air. All the above advantages provided a good potential for their industrial application and we believe they will play an important role in near future.

\section{Acknowledgement}

This work was supported by the National Natural Science Foundation of China (Nos. 51473170 and 21871275). B. G. is grateful to the CAS-TWAS President's fellowship.

\section{References}

[1] Johnson, L. K.; Killian, C. M.; Brookhart, M. J. Am. Chem. Soc. 1995, 117, 6414.

[2] Small, B. L.; Brookhart, M.; Bennet, A. M. A. J. Am. Chem. Soc. 1998, 120, 4049

[3] Britovsek, G. J. P.; Gibson, V. C.; Kimberley, B. S.; Maddox, P. J.; McTavish, S. J.; Solan, G. A.; Whitea, A. J. P.; Williams, D. J. Chem. Commun. 1998, 7, 849 .

[4] Gibson, V. C.; Redshaw, C.; Solan, G. A. Chem. Rev. 2007, 107, 1745

[5] Xiao, T.; Zhang, W.; Lai, J.; Sun, W.-H. C. R. Chim. 2011, 14, 851.

[6] Zhang, W.; Sun, W.-H.; Redshaw, C. Dalton Trans. 2013, 42, 8988

[7] Bianchini, C.; Giambastiani, G.; Rios, I. G.; Mantovani, G.; Meli, A.; Segarra, A. M. Coord. Chem. Rev. 2006, 250, 1391.

[8] Flisak, Z.; Sun, W.-H. ACS Catal. 2015, 5, 4713.

[9] Gibson, V. C.; Solan, G. A. Olefin Oligomerizations and Polymerizations Catalyzed by Iron and Cobalt Complexes Bearing Bis(imino)pyridine Ligands, In Catalysis without Precious Metals, Ed.: Bullock, M., Wiley-VCH, Weinheim, 2010, pp. 111-141.

[10] Gibson, V. C.; Solan, G. A. Top. Organomet. Chem. 2009, 26 ,
107

[11] Bianchini, C.; Giambastiani, G.; Luconi, L.; Meli, A. Coord. Chem. Rev. 2010, 254, 431.

[12] Wang, Z.; Liu, Q.; Solan, G. A.; Sun, W.-H. Coord. Chem. Rev. 2017, 350, 68 .

[13] Wang, Z.; Solan, G. A.; Zhang, W.; Sun, W.-H. Coord. Chem. Rev. 2018, 363, 92

[14] Suo, H.; Solan, G. A.; Ma, Y.; Sun, W.-H. Coord. Chem. Rev. 2018, 372, 101.

[15] Wang, S.; Du, S.; Zhang, W.; Asuha, S.; Sun, W.-H. Chem. Open 2015, 4, 328.

[16] Zhang, M.; Zhang, W.; Xiao, T.; Xiang, J.-F.; Hao, X.; Sun, W.-H. J. Mol. Catal. A: Chem. 2010, 320, 92

[17] Du, S.; Zhang, W.; Yue, E.; Huang, F.; Liang, T.; Sun, W.-H. Eur. J. Inorg. Chem. 2016, 1748.

[18] Xing, Q.; Zhao, T.; Du, S.; Yang, W.; Liang, T.; Redshaw, C.; Sun, W.-H. Organometallics 2014, 33, 1382

[19] Sun, W.-H.; Zhao, W.; Yu, J.; Zhang, W.; Hao, X.; Redshaw, C. Macromol. Chem. Phys. 2012, 213, 1266.

[20] Sun, Z.; Yue, E.; Qu, M.; Oleynik, I. V.; Oleynik, II.; Liang, K.; Li, T.; Zhang, W.; Sun, W.-H. Inorg. Chem. Front. 2015, 2, 223.

[21] Liu, H.; Zhao, W.; Yu, J.; Yang, W.; Hao, X.; Redshaw, C.; Chen, L.; Sun, W.-H. Catal. Sci. Technol. 2012, 2, 415

[22] Fan, L.; Yue, E.; Du, S.; Guo, C.-Y.; Hao, X.; Sun, W.-H. RSC Adv. 2015, 5, 93274.

[23] Du, S.; Kong, S.; Shi, Q.; Mao, J.; Guo, C.; Yi, J.; Liang, T.; Sun, W.-H. Organometallics 2015, 34, 582.

[24] Wang, X.; Fan, L.; Ma, Y.; Guo, C.-Y.; Solan, G. A.; Sun, Y.; Sun, W.-H. Polym. Chem. 2017, 8, 2785

[25] Suo, H.; Oleynik, I. V.; Huang, C.; Oleynik, I. I.; Solan, G. A.; Ma, Y.; Liang, T.; Sun, W.-H. Dalton. Trans. 2017, 46, 15684.

[26] Wu, R.; Wang, Y.; Zhang, R.; Guo, C.-Y.; Flisak, Z.; Sun, Y.; Sun, W.-H. Polymer 2018, 153, 574

[27] Mahmood, Q.; Zeng, Y.; Yue, E.; Solan, G. A.; Liang, T.; Sun, W.-H. Polym. Chem. 2017, 8, 6416

[28] Speiser, F.; Braunstein, P.; Saussine, L. Acc. Chem. Res. 2005, 38, 784.

[29] Speiser, F.; Braunstein, P.; Saussine, L.; Welter, R. Inorg. Chem. 2004, 43, 1649

[30] Speiser, F.; Braunstein, P.; Saussine, L.; Welter, R. Organometallics 2004, 23, 2613.

[31] Ghisolfi, A.; Fliedel, C.; Rosa, V.; Monakhov, K. Y.; Braunstein, P. Organometallics 2014, 33, 2523.

[32] Boudier, A.; Breuil, P. A. R.; Magna, L.; Olivier-Bourbigou, H.; Braunstein, P. Dalton Trans. 2015, 44, 12995.

[33] Chavez, P.; Rios, I. G.; Kermagoret, A.; Pattacini, R.; Meli, A.; Bianchini, C.; Giambastiani, G.; Braunstein, P. Organometallics 2009, 28, 1776 .

[34] Hamada, A.; Braunstein, P. Inorg. Chem. 2009, 48, 1624.

[35] Killian, C. M.; Johnson, L. K.; Brookhart, M. Organometallics 1997, 16, 2005

[36] Svejda, S. A.; Brookhart, M. Organometallics 1999, 18, 65.

[37] Liu, F.; Hu, H.; Xu, Y.; Guo, L.; Zai, S.; Song, K.; Gao, H.; Zhang, L.; Zhu, F.; Wu, Q. Macromolecules 2009, 42, 7789.

[38] Rose, J. M.; Cherian, A. E.; Coates, G. W. J. Am. Chem. Soc 2006, $128,4186$.

[39] Helldörfer, M.; Milius, W.; Alt, H. G. J. Mol. Catal. A: Chem. 2003, 197, 1.

[40] Schmid, M.; Eberhardt, R.; Klinga, M.; Leskelä, M.; Rieger, B. Organometallics 2001, 20, 2321.

[41] Bahuleyan, B. K.; Son, G. W.; Park, D. W.; Ha, C. S.; Kim, I. J. Polym. Sci. Part A: Polym. Chem. 2008, 46, 1066.

[42] Guan, Z.; Cotts, P. M.; McCord, E. F.; McLain, S. J. Science 1999, 283, 2059.

[43] Liu, H.; Zhao, W.; Hao, X.; Redshaw, C.; Huang, W.; Sun, W.-H. Organometallics 2011, 30, 2418. 
[44] Kong, S.; Guo, C.-Y.; Yang, W.; Wang, L.; Sun, W.-H.; Glaser, R. J. Organomet. Chem. 2013, 725, 37.

[45] Fan, L.; Du, S.; Guo, C.-Y.; Hao, X.; Sun, W.-H. J. Polym. Sci. Part A: Polym. Chem. 2015, 53, 1369.

[46] Mahmood, Q.; Zeng, Y.; Wang, X.; Sun, Y.; Sun, W.-H. Dalton Trans. 2017, 46, 6934.

[47] Huang, C.; Zakharov, V. A.; Semikolenova, N. V.; Matsko, M. A.; Mahmood, Q.; Talsi, E. P.; Sun, W.-H. J. Catal. 2019, 372, 103.

[48] Du, S.; Xing, Q.; Flisak, Z.; Yue, E.; Sun, Y.; Sun, W.-H. Dalton Trans. 2015, 44, 12282.

[49] Chen, Y.; Du, S.; Huang, C.; Solan, G. A.; Hao, X.; Sun, W.-H. J. Polym. Sci. Part A: Polym. Chem. 2017, 55, 1971.

[50] Zhang, Q.; Zhang, R.; Ma, Y.; Solan, G. A.; Liang, T.; Sun, W.-H Appl. Catal. A-Gen. 2019, 573, 73.

[51] Wang, X.; Fan, L.; Yuan, Y.; Du, S.; Sun, Y.; Solan, G. A.; Gao, C.-Y.; Sun, W.-H. Dalton Trans. 2016, 45, 18313.

[52] Wen, C.; Yuan, S.; Shi, Q.; Yue, E.; Liu, D.; Sun, W.-H. Organometallics 2014, 33, 7223.

[53] Yuan, S.; Yue, E.; Wen, C.; Sun, W.-H. RSC Adv. 2016, 6, 7431.

[54] Song, S.; Xiao, T.; Liang, T.; Wang, F.; Redshaw, C.; Sun, W.-H. Catal. Sci. Technol. 2011, 1, 69.

[55] Yu, J.; Hu, X.; Zeng, Y.; Zhang, L.; Ni, C.; Hao, X.; Sun, W.-H. New J. Chem. 2011, 35, 178.

[56] Hou, X.; Liang, T.; Sun, W.-H.; Redshaw, C.; Chen, X. J. Organomet. Chem. 2012, 708, 98.

[57] Chai, W.; Yu, J.; Wang, L.; Hu, X.; Redshaw, C.; Sun, W.-H. Inorg. Chim. Acta 2012, 385, 21.

[58] Zhang, L.; Castillejos, E.; Serp, P.; Sun, W.-H.; Durand, J. Catal. Today 2014, 235, 33.

[59] Soshnikov, I. E.; Semikolenova, N. V.; Bryliakov, K. P.; Zakharov, V. A.; Sun, W.-H.; Talsi, E. P. Organometallics 2015, 34,3222

[60] Huang, F.; Sun, Z.; Du, S.; Yue, E.; Ba, J.; Hu, X.; Liang, T.; Galland, G. B.; Sun, W.-H. Dalton Trans. 2015, 44, 14281.

[61] Sun, Z.; Huang, F.; Qu, M.; Yue, E.; Oleynik, I. V.; Oleynik, I. I.; Zeng, Y.; Liang, T.; Li, K.; Zhang, W.; Sun, W.-H. RSC Adv. 2015, 5, 77913.

[62] Zhang, R.; Wang, Z.; Flisak, Z.; Hao, X.; Liu, Q.; Sun, W.-H. J. Polym. Sci. Part A: Polym. Chem. 2017, 55, 2601.

[63] Guo, L.; Zhu, D.; Zhang, W.; Zada, M.; Solan, G. A.; Hao, X.; Sun, W.-H. Eur. Polym. J. 2018, 107, 315.

[64] Zhang, Y.; Huang, C.; Wang, X.; Mahmood, Q.; Hao, X.; Hu, X.; Guo, C.-Y.; Solan, G. A.; Sun, W.-H. Polym. Chem. 2017, 8, 995.

[65] Huang, C.; Zeng, Y.; Flisak, Z.; Zhao, Z.; Liang, T.; Sun, W.-H. J. Polym. Sci. Part A: Polym. Chem. 2017, 55, 2071.

[66] Yue, E.; Zhang, L.; Xing, Q.; Cao, X.; Hao, X.; Redshaw, C.; Sun W.-H. Dalton Trans. 2014, 43, 423.

[67] Yue, E.; Xing, Q.; Zhang, L.; Shi, Q.; Cao, X.; Wang, L.; Redshaw, C.; Sun, W.-H. Dalton Trans. 2014, 43, 3339.

[68] Younkin, T. R.; Connor, E. F.; Henderson, J. I.; Friedrich, S. K.; Grubbs, R. H.; Bansleben, D. A. Science 2000, 287, 460.

[69] Keim, W.; Killat, S.; Nobile, C. F.; Suranna, G. P.; Englert, U.; Wang, R.; Mecking, S.; Schröder, D. L. J. Organomet. Chem. 2002, 662, 150.

[70] Chen, L. Y.; Hou, J. X.; Sun, W.-H. Appl. Catal. A-Gen. 2003, 246, 11.

[71] Chang, F.; Zhang, D.; Xu, G.; Yang, H.; Li, J.; Song, H.; Sun, W.-H. J. Organomet. Chem. 2004, 689, 936.

[72] Hou, J.; Sun, W.-H.; Zhang, D.; Chen, L.; Li, W.; Zhao, D.; Son, H. J. Mol. Catal. A: Chem. 2005, 231, 221.

[73] Zhang, D.; Du, J.; Han, L.; Sun, W.-H. Chin. J. Struc. Chem. 2005, 24, 930.

[74] Zhou, Z.; Hao, X.; Redshaw, C.; Chen, L.; Sun, W.-H. Catal. Sci. Technol. 2012, 2, 1340 .

[75] Wang, S.; Sun, W.-H.; Redshaw, C. J. Organomet. Chem. 2014, 751,717
[76] Gao, R.; Sun, W.-H.; Redshaw, C. Catal. Sci. Technol. 2013, 3, 1172.

[77] Lai, J.; Hou, X.; Liu, Y.; Redshaw, C.; Sun, W.-H. J. Organomet. Chem. 2012, 702, 52.

[78] Chen, Y.; Hao, P.; Zuo, W.; Gao, K.; Sun, W.-H. J. Organomet. Chem. 2008, 693, 1829

[79] Gao, R.; Zhang, M.; Liang, T.; Wang, F.; Sun, W.-H. Organometallics 2008, 27, 5641.

[80] Xiao, L.; Zhang, M.; Gao, R.; Cao, X.; Sun, W.-H. Aust. J. Chem 2010, 63, 109

[81] Chen, X.; Zhang, L.; Yu, J.; Hao, X.; Liu, H.; Sun, W.-H. Inorg. Chim. Acta 2011, 370, 156.

[82] Shi, Q.; Zhang, S.; Chang, F.; Hao, P.; Sun, W.-H. Comptes Rendus Chimie 2007, 10, 1200.

[83] Song, K.; Yang, W.; Li, B.; Liu, Q.; Redshaw, C.; Li, Y.; Sun, W.-H. Dalton Trans. 2013, 42, 9166.

[84] Kong, S.; Song, K.; Liang, T.; Guo, C.-Y.; Sun, W.-H.; Redshaw, C. Dalton Trans. 2013, 42, 9176.

[85] Sturzel, M.; Mihan, S.; Mulhaupt, R. Chem. Rev. 2016, 116 , 1398.

[86] Guo, N.; Hu, M.-Y.; Feng, Y.; Zhu, S.-F. Org. Chem. Front. 2015, 2, 692.

[87] Rezayee, N. M.; Samblanet, D. C.; Sanford, M. S. ACS Catal. 2016, 6, 6377

[88] Chakraborty, S.; Dai, H.; Bhattacharya, P.; Fairweather, N. T.; Gibson, M. S.; Krause, J. A.; Guan, H. J. Am. Chem. Soc. 2014 136, 7869

[89] Werkmeister, S.; Junge, K.; Wendt, B.; Alberico, E.; Jiao, $\mathrm{H}$. Baumann, W.; Junge, H.; Gallou, F.; Beller, M. Angew. Chem. Int. Ed. 2014, 53, 8722.

[90] Yuwen, J.; Chakraborty, S.; Brennessel, W. W.; Jones, W. D. ACS Catal. 2017, 7, 3735

[91] Srimani, D.; Mukherjee, A.; Goldberg, A. F.; Leitus, G.; DiskinPosner, Y.; Shimon, L. J.; David, Y. B.; Milstein, D. Angew. Chem. Int. Ed. 2015, 54, 12357.

[92] Fu, S.; Chen, N.-Y.; Liu, X.; Shao, Z.; Luo, S.-P.; Liu, Q. J. Am. Chem. Soc. 2016, 138, 8588

[93] Korstanje, T. J.; Vlugt, J. I.; Elsevier, C. J.; Bruin, B. Science 2015, 350, 298

[94] Mukherjee, A.; Srimani, D.; Chakraborty, S.; Ben-David, Y.; Milstein, D. J. Am. Chem. Soc. 2015, 137, 8888

[95] Alberico, E.; Sponholz, P.; Cordes, C.; Nielsen, M.; Drexler, H. J.; Baumann, W.; Junge, H.; Beller, M. Angew. Chem. Int. Ed. 2013, 52, 14162.

[96] Mellone, I.; Gorgas, N.; Bertini, F.; Peruzzini, M.; Kirchner, K. Gonsalvi, L. Organometallics 2016, 35, 3344.

[97] Bielinski, E. A.; Förster, M.; Zhang, Y.; Bernskoetter, W. H.; Hazari, N.; Holthausen, M. C. ACS Catal. 2015, 5, 2404

[98] Chakraborty, S.; Lagaditis, P. O.; Förster, M.; Bielinski, E. A.; Hazari, N.; Holthausen, M. C.; Jones, W. D.; Schneider, S. ACS Catal. 2014, 4, 3994.

[99] Zhang, G.; Hanson, S. K. Org. Lett. 2013, 15, 650

[100] E. Balaraman, A. Nandakumar, G. Jaiswal, M.K. Sahoo, Catal. Sci. Technol. 2017, 7, 3177

[101] Li Y-Y, Yu S-L, Shen W-Y, Gao J-X, Acc. Chem. Res. 2015, 48 2587.

[102] Daw P, Chakraborty S, Garg JA, Ben-David Y, Milstein D, Angew. Chem. Int. Ed. 2016, 55, 14373.

[103] Yin Z, Zeng H, Wu J, Zheng S, Zhang G, ACS Catal. 2016, 6 , 6546

[104] Deibl, N.; Kempe, R. J. Am. Chem. Soc. 2016, 138, 10786.

[105] Takeuchi, D.; Osakada, K. Polymer 2008, 49, 4911.

[106] Takeuchi, D.; Matsuura, R.; Fukuda, Y.; Osakada, K. Dalton Trans. 2009, 8955.

[107] Gong, D.; Zhang, X.; Huang, K.-W. Dalton Trans. 2016, 45 19399

[108] Ma, J.; Feng, C.; Wang, S.; Zhao, K.-Q.; Sun, W.-H.; Redshaw, 
C.; Solan, G. A. Inorg. Chem. Front. 2014, 1, 14.

[109] Britovsek, G. J. P.; Bruce, M.; Gibson, V. C.; Kimberley, B. S.; Maddox, P. J.; Mastroianni, S.; McTavish, S. J.; Redshaw, C.; Solan, G. A.; Stromberg, S.; White, A. J. P.; Williams, D. J. J. Am. Chem. Soc. 1999, 121, 8728.

[110] Small, B. L.; Brookhart, M. J. Am. Chem. Soc. 1998, 120, 7143.

[111] Britovsek, G. J. P.; Mastroianni, S.; Solan, G. A.; Baugh, S. P. D.; Redshaw, C.; Gibson, V. C.; White, A. J. P.; Williams, D. J.; Elsegood, M. R. Chem. Eur. J. 2000, 6, 2221

[112] Chen, Y.; Qian, C.; Sun, J. Organometallics 2003, 22, 1231.

[113] Chen, Y.; Chen, R.; Qian, C.; Dong, X.; Sun, J. Organometallics 2003, 22, 4312.

[114] Görl, C.; Alt, H. G. J. Mol. Catal. A: Chem. 2007, 273, 118.

[115] Kaul, F. A. R.; Puchta, G. T.; Frey, G. D.; Herdtweck, E.; Herrmann, W. A. Organometallics 2007, 26, 988.

[116] Ionkin, A. S.; Marshall, W. J.; Adelman, D. J.; Fones, B. B.; Fish, B. M.; Schiffhauer, M. F.; Soper, P. D.; Waterland, R. L.; Spence, R. E.; Xie, T. J. Polym. Sci., Part A: Polym. Chem. 2008, 46, 585.

[117] Ionkin, A. S.; Marshall, W. J.; Adelman, D. J.; Fones, B. B.; Fish, B. M.; Schiffhauer, M. F. Organometallics 2008, 27, 1902.

[118] Wallenhorst, G.; Kehr, G.; Luftmann, H.; Fröhlich, R.; Erker, G. Organometallics 2008, 27, 6547.

[119] Cámpora, J.; Naz, A. M.; Palma, P. Eur. J. Inorg. Chem. 2008, 1871.

[120] Long, Z.; Wu, B.; Yang, P.; Li, G.; Liu, Y.; Yang, X.-J. J. Organomet. Chem. 2009, 694, 3793.

[121] Xie, G.; Li, T.; Zhang, A. Inorg. Chem. Commun. 2010, 13, 1199.

[122] Guo, L.-H.; Gao, H.-Y.; Zhang, L.; Zhu, F.-M.; Wu, Q. Organometallics 2010, 29, 2118.

[123] Yu, J.; Liu, H.; Zhang, W.; Hao, X.; Sun, W.-H. Chem. Commun. 2011, 47, 3257

[124] Yu, J.; Huang, W.; Wang, L.; Redshaw, C.; Sun, W.-H. Dalton Trans. 2011, 40, 10209.

[125] Cao, X.; He, F.; Zhao, W.; Cai, Z.; Hao, X.; Shiono, T.; Redshaw, C.; Sun, W.-H. Polymer 2012, 53, 1870.

[126] He, F.; Zhao, W.; Cao, X.-P.; Liang, T.; Redshaw, C.; Sun, W.-H. J. Organomet. Chem. 2012, 713, 209.

[127] Mahmood, Q.; Yue, E.; Guo, J.; Zhang, W.; Ma, Y.; Hao, X.; Sun, W.-H. Polymer 2018, 159, 124.

[128] Mahmood, Q.; Guo, J.; Zhang, W.; Ma, Y.; Liang, T.; Sun, W.-H. Organometallics 2018, 37, 957.

[129] Sun, W.-H.; Zhao, W.; Yu, J.; Zhang, W.; Hao, X.; Redshaw, C. Macromol. Chem. Phys., 2012, 213, 1266.

[130] Wang, S.; Zhao, W.; Hao, X.; Li, B.; Redshaw, C.; Li, Y.; Sun, W.-H. J. Organomet. Chem. 2013, 731, 78.

[131] Zhao, W.; Yu, J.; Song, S.; Yang, W.; Liu, H.; Hao, X.; Redshaw, C.; Sun, W.-H. Polymer 2012, 53, 130.

[132] Lai, J.; Zhao, W.; Yang, W.; Redshaw, C.; Liang, T.; Liu, Y.; Sun, W.-H. Polym. Chem. 2012, 3, 787.

[133] Zhang, W.; Wang, S.; Du, S.; Guo, C.-Y.; Hao, X.; Sun, W.-H. Macromol. Chem. Phys. 2014, 215, 1797.

[134] Wang, S.; Li, B.; Liang, T.; Redshaw, C.; Li, Y.; Sun, W.-H. Dalton Trans. 2013, 42, 9188.

[135] Zhao, W.; Yue, E.; Wang, X.; Yang, W.; Chen, Y.; Hao, X.; Cao, X.; Sun, W.-H. J. Polym. Sci., Part A: Polym. Chem. 2017, 55, 988.

[136] Wang, L.; Sun, W.-H.; Han, L.; Yang, H.; Hu, Y.; Jin, X. J. Organomet. Chem. 2002, 658, 62.

[137] Britovsek, G. J. P.; Baugh, S. P. D.; Hoarau, O.; Gibson, V. C.; Wass, D. F.; White, A. J. P.; Williams, D. J. Inorg. Chim. Acta 2003, 345, 279.

[138] Sun, W.-H.; Jie, S.; Zhang, S.; Zhang, W.; Song, Y.; Ma, H. Organometallics 2006, 25, 666.

[139] Jie, S.; Zhang, S.; Sun, W.-H.; Kuang, X.; Liu, T.; Guo, J. J. Mol. Catal. A: Chem. 2007, 269, 85.
[140] Pelletier, J. D. A.; Champouret, Y. D. M.; Cadarso, J.; Clowes, L.; Gañete, M.; Singh, K.; Thanarajasingham, V.; Solan, G. A. J. Organomet. Chem. 2006, 691, 4114.

[141] .Zhang, M.; Zhang, W.; Xiao, T.; Xiang, J.-F.; Hao, X.; Sun, W.-H. J. Mol. Catal. A: Chem. 2010 320, 92.

[142] Jie, S.; Zhang, S.; Sun, W.-H. Eur. J. Inorg. Chem. 2007, 5584.

[143] Zhang, M.; Hao, P.; Zuo, W.; Jie, S.; Sun, W.-H. J. Organomet. Chem. 2008, 693, 483.

[144] Zhang, M.; Gao, R.; Hao, X.; Sun, W.-H. J. Organomet. Chem. 2008, 693, 3867.

[145] Sun, W.-H.; Hao, P.; Li, G.; Zhang, S.; Wang, W.; Yi, J.; Asma, M.; Tang, N. J. Organomet. Chem. 2007, 692, 4506.

[146] Xiao, L.; Gao, R.; Zhang, M.; Li, Y.; Cao, X.; Sun, W.-H Organometallics 2009, 28, 2225.

[147] Sun, W.-H.; Hao, P.; Zhang, S.; Shi, Q.; Zuo, W.; Tang, X.; Lu, X. Organometallics 2007, 26, 2720.

[148] Chen, Y.; Hao, P.; Zuo, W.; Gao, K.; Sun, W.-H. J. Organomet. Chem. 2008, 693, 1829.

[149] Zhang, L.; Hou, X.; Yu, J.; Chen, X.; Hao, X.; Sun, W.-H. Inorg. Chim. Acta 2011, 379, 70.

[150] Gao, R.; Li, Y.; Wang, F.; Sun, W.-H. Eur. J. Inorg. Chem. 2009, 309, 166.

[151] Song, S.; Gao, R.; Zhang, M.; Li, Y.; Wang, F.; Sun, W.-H. Inorg. Chim. Acta 2011, 376, 373.

[152] Lenges, G. M. U. S. Pat. 0061987, 2002, A1.

[153] Nakayama, Y.; Baba, Y.; Yasuda, H.; Kawakita, K.; Ueyama, N. Macromolecules 2003, 36, 7953.

[154] Zabel, D.; Schubert, A.; Wolmershäuser, G.; Jones, J. R. L.; Thiel, W. R. Eur. J. Inorg. Chem. 2008, 3648.

[155] Tenza, K.; Hanton, M. J.; Slawin, A. M. Z. Organometallics 2009, $28,4852$.

[156] Wang, K.; Wedeking, K.; Sun, W.-H. J. Organomet. Chem. 2008, 693,1073

[157] Zhang, S.; Sun, W.-H.; Hao, X. Organometallics 2010, 29, 1168.

[158] Xiao, T.; Zhang, S.; Sun, W.-H. Polymer 2011, 52, 5803.

[159] Zhang, W.; Chai, W.; Sun, W.-H.; Hu, X.; Redshaw, C.; Hao, X. Organometallics 2012, 31, 5039.

[160] Sun, W.-H.; Kong, S.; Chai, W.; Shiono, T.; Redshaw, C.; Hu, X.; Guo, C.; Hao, X. Appl. Catal. A: Gen. 2012, 67.

[161] Huang, Y.; Zhang, R.; Liang, T.; Hu, X.; Solan, G. A.; Sun, W.-H. Organometallics 2019, 38, 1143.

[162] Ba, J.; Du, S.; Yue, E.; Hu, X.; Flisak, Z.; Sun, W.-H. RSC Adv. 2015, 5, 32720.

[163] Huang, F.; Xing, Q.; Liang, T.; Flisak, Z.; Ye, B.; Hu, X.; Yang, W.; Sun, W.-H. Dalton Trans. 2014, 43, 16818.

[164] Zhang, Y.; Suo, H.; Huang, F.; Liang, T.; Hu, X.; Sun, W.-H. J. Polym. Sci., Part A: Polym. Chem. 2017, 55, 830.

[165] Huang, F.; Zhang, W.; Sun, Y.; Hu, X.; Solan, G. A.; Sun, W.-H. New J. Chem. 2016, 40, 8012.

[166] Huang, F.; Zhang, W.; Yue, E.; Liang, T.; Hu, X.; Sun, W.-H. Dalton Trans. 2016, 45, 657.

[167] Appukuttan, V. K.; Liu, Y.; Son, B. C.; Ha, C.-S.; Suh, H.; Kim, I. Organometallics 2011, 30, 2285.

[168] Du, S.; Wang, X.; Zhang, W.; Flisak, Z.; Sun, Y.; Sun, W.-H. Polym. Chem. 2016, 7, 4188.

[169] Du, S.; Zhang, W.; Yue, E.; Huang, F.; Liang, T.; Sun, W.-H. Eur. J. Inorg. Chem. 2016, 1748.

[170] Bariashir, C.; Wang, Z.; Ma, Y.; Vignesh, A.; Hao, X.; Sun, W.-H. Organometallics 2019, 38, 4455.

[171] Bariashir, C.; Wang, Z.; Du, S.; Solan, G. A.; Huang, C.; Liang, T.; Sun, W.-H. J. Polym. Sci. A Polym. Chem. 2017, 55, 3980.

[172] Wang, Z.; Zhang, R.; Zhang, W.; Solan, G. A.; Liu, Q.; Liang, T.; Sun, W.-H. Catal. Sci. Technol. 2019, 9, 1933.

[173] Wang, Z.; Solan, G. A.; Mahmood, Q.; Liu, Q.; Ma, Y.; Hao, X.; Sun, W.-H. Organometallics 2018, 37, 380.

[174] Wang, Z.; Ma, Y.; Guo, J.; Liu, Q.; Solan, G. A.; Liang, T.; Sun, 
W.-H. Dalton Trans. 2019, 48, 2582.

[175] Wang, Z.; Solan, G. A.; Ma, Y.; Liu, Q.; Liang, T.; Sun, W.-H. Research 2019, e9426063, DOI:10.34133/2019/9426063.

[176] Cossee, P. J. Catal. 1964, 3, 80.

Received November 9, 2019 Accepted December 1, 2019 